\title{
THE INFLUENCE OF VIDEO-BASED MEDIA MULTIPLICATION BOARDS IN IMPROVING MATHEMATICS LEARNING OUTCOMES FOR MI PLUS GRADE II STUDENTS AL- ISTIGHOTSAH TULUNGAGUNG
}

\author{
Submitted: \\ 6 Juli 2021 \\ Accepted: \\ 18 Desember 2021 \\ Published: \\ 31 Januari 2022
}

\author{
Lina Jinatul Falah*1, Eni Setyowati², H. Akhyak ${ }^{3}$ \\ Linafalah38@gmail.com ${ }^{1}$, eniiaintulungagung@gmail.com ${ }^{2}$, \\ akhyakyunis@yahoo.co.id ${ }^{3}$ \\ Pendidikan Guru Madrasah Ibtidaiyah \\ Pascasarjana IAIN Tulungagung
}

\begin{abstract}
Based on the results of interviews conducted by researchers at MI Plus AlIstighotsah Tulungagung, it was known that the online learning process has not used learning media, only asking students to read, observe and do assignments. So that they do not understand the multiplication material being studied. This study aims to explain the effect of video-based multiplication board media in improving mathematics learning outcomes for class II students MI Plus Al-Istighotsah Tulungagung. This research is a quasi-experimental research with a quantitative approach. Data collection techniques using tests. Based on data analysis, it can be seen that there is a significant difference between learning that received special treatment (using video-based multiplication board media) and learning that did not receive special treatment. This can be seen from the results of the analysis on the t-test that the t-count value is 2,087, while the t-table value is 1,697 at the $5 \%$ significance level with $\mathrm{db}=\mathrm{N}-2=56-2=54$. Based on the results of tcount with ttable it can be concluded that tcount $>t$ table is 2,087>1,697 with sig. (2-tiled) is $0.042<0.05$. Based on the results of the study, it can be concluded that there is an effect of video-based multiplication board media in improving mathematics learning outcomes for class II students of MI Plus Al - Istighotsah Tulungagung.
\end{abstract}

Keywords: Media Multiplication Board, Video-Based, Mathematics Learning Outcomes

\section{INTRODUCTION}

In China, in the city of Wuhan, in early 2020, a virus that can disrupt the respiratory tract and can lead to death, namely the corona virus. Corona virus has entered many countries. One of them is Indonesia. The COVID-19 outbreak entered Indonesia on March 12, 2020. The impact of the COVID-19 pandemic has changed various aspects of life. One of them is education. To prevent the transmission of the corona virus, education is carried out remotely or online. This online learning challenges all elements, from teachers, students to parents. Education which was 
initially carried out face-to-face, due to the COVID-19 pandemic, education had to be done online. According to Luh Devi Herlindry (2020), online education is considered effective for carrying out learning even though it is in a different place. Online learning urges an educator to innovate and adapt to the use of technology. The utilization of technology in learning can be used in all subjects.

The learning process carried out at MI Plus Al-Istighotsah Tulungagung was carried out online without using learning media, only asking students to read, observe and do assignments. So that they do not understand the multiplication material being studied. This can be seen from the results of the multiplication material math test with an average value of students is 67. Many of the results of these tests have not been completed.

Researchers are interested in researching the development of video-based multiplication board media at MI Plus Al-Istighosah Tulungagung with the reason that the school has not used video-based Multiplication Board media and from the principals and teachers are very enthusiastic about the video-based Multiplication Board media which later can help improve students' mathematics learning outcomes in online learning. The multiplication board media is proven to be able to help students improve learning outcomes following the article Inarotul Humaero et al, with the titled efforts to improve the Mathematics Learning Outcomes of Multiplication Materials through the Class III Napier Board Media at SDN Kalisabuk 03 2019. In this journal, the Napier board is used as a multiplication medium. The Napier board is made of styrofoam modified with number cards, where there is a series of additions and a series of multipliers. The results of the study were obtained from the first cycle with an average value of 67.59 with a completeness percentage of $45.45 \%$, while in the second cycle the score increased by an average of 80.04 with a completeness percentage of $77.27 \%$. Thus it can be concluded that there is an increase in the value of the use of Napier board media.

Based on the problems above, the researcher formulates the problem formulation, how does the influence of multiplication board media video-based in improving mathematics learning outcomes for class II students MI Plus AlIstighotsahTulungagung. The purpose of this study is to explain the effect of 
multiplication board media video-based in improving grade II mathematics learning outcomes MI Plus Al-Istighotsah Tulungagung.

\section{METHOD}

This research used a quantitative research approach with a quasi-experimental type of research. According to Kerlinger, (2006:215) in all experimental research is a study with the control class group and the experimental class having the same ability. The experimental class was given special treatment, while the control class was not given special treatment. Then the results of the two are compared to determine whether there is an effect of special treatment from the experimental class.

This study used a population of all class II, which amounted to 79 students. The researcher used a research sample of class II C as the experimental class, which consisted of 28 students, and class II B as the control class with 28 students. To obtain the research sample, the researcher used a cluster sampling technique. As for data collection using a test with two types of questions, which are five multiple-choice questions and five fill-in questions. Researchers used data analysis techniques using ttest with SPSS 16.0.

\section{RESULTS}

This research was conducted at MI Plus Al - Istighotsah Tulungagung with class II as the research object. Researchers used tests as data collection. Post-test questions before being given to class II students of MI Plus Al - Istighotsah Tulungagung, first were corrected by a question expert and then tested on 10 class II students from other schools to test the validation and reliability of the questions. After the post-test questions are valid and reliable, they can be used on the research sample. Based on research on the effect of multiplication board media video-based in improving mathematics learning outcomes for class II students MI Plus Al-Istighotsah Tulungagung obtained the following data: 
Table. 1. Homogeneity Test Results Students' Daily Test Values

Test of Homogeneity of Variances

Daily test score

\begin{tabular}{|c|c|c|c|}
\hline Levene Statistic & df1 & df2 & Sig. \\
\hline .199 & 2 & 75 & .820 \\
\hline
\end{tabular}

Based on the results of the table above, it can be seen that the significance is 0.820 so that it is obtained $0.820>0.05$, then the three have no difference in ability, so they can be used as research samples.

Table 2. Output Validation Test of Multiple Choice Questions

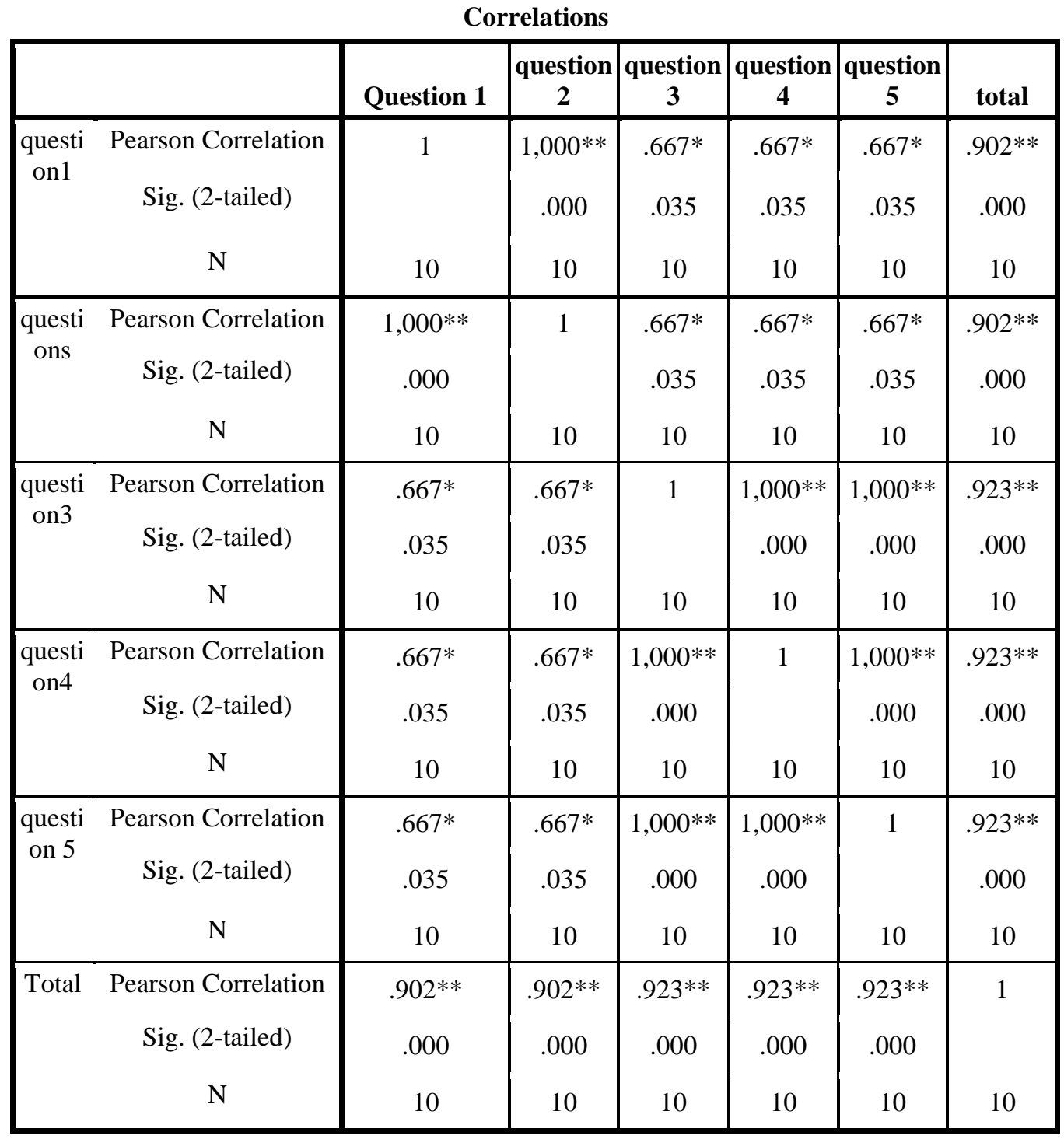


Based on the table above, it can be concluded that from 10 respondents the rtable value is 0.632 . From questions number 1 to number 5 , the values of rcount rtable are (0.902 0.632), (0.902 0.632), (0.923 0.632), (0.923 0.632), (0.902 0.632) are declared valid.

Table 3. Results of the Validation Test Using SPSS 16.0

Correlations

\begin{tabular}{|c|c|c|c|c|c|c|c|}
\hline & & $\begin{array}{c}\text { question } \\
6\end{array}$ & \begin{tabular}{|c|} 
questio \\
n7 \\
\end{tabular} & \begin{tabular}{|c|} 
question \\
8 \\
\end{tabular} & \begin{tabular}{|c|} 
question \\
9 \\
\end{tabular} & \begin{tabular}{|c} 
question \\
10
\end{tabular} & total \\
\hline $\begin{array}{c}\text { question } \\
6\end{array}$ & $\begin{array}{l}\text { Pearson Correlation } \\
\qquad \begin{array}{c}\text { Sig. (2-tailed) } \\
\text { N }\end{array}\end{array}$ & 10 & $\begin{array}{c}.716^{*} \\
.020 \\
10\end{array}$ & $\begin{array}{c}.764 * \\
.010 \\
10\end{array}$ & $\begin{array}{l}.600 \\
.067 \\
10\end{array}$ & $\begin{array}{l}.764 * \\
.010 \\
10\end{array}$ & $\begin{array}{c}.856^{* *} \\
.002 \\
10\end{array}$ \\
\hline question7 & $\begin{array}{l}\text { Pearson Correlation } \\
\text { Sig. (2-tailed) } \\
\text { N }\end{array}$ & $\begin{array}{l}.716^{*} \\
.020 \\
10\end{array}$ & 10 & $\begin{array}{c}.937 * * \\
.000 \\
10\end{array}$ & $\begin{array}{l}.820 * * \\
.004 \\
10\end{array}$ & $\begin{array}{c}.937 * * \\
.000 \\
10\end{array}$ & $\begin{array}{c}.938 * * \\
.000 \\
10\end{array}$ \\
\hline $\begin{array}{c}\text { question } \\
8\end{array}$ & $\begin{array}{l}\text { Pearson Correlation } \\
\text { Sig. (2-tailed) } \\
\text { N }\end{array}$ & $\begin{array}{c}.764^{*} \\
.010 \\
10\end{array}$ & $\begin{array}{c}.937 * * \\
.000 \\
10\end{array}$ & 10 & $\begin{array}{c}.875^{* *} \\
.001 \\
10\end{array}$ & $\begin{array}{c}1,000 * * \\
.000 \\
10\end{array}$ & $\begin{array}{c}.972 * * \\
.000 \\
10\end{array}$ \\
\hline question9 & $\begin{array}{l}\text { Pearson Correlation } \\
\qquad \text { Sig. (2-tailed) } \\
\text { N }\end{array}$ & $\begin{array}{l}.600 \\
.067 \\
10\end{array}$ & $\begin{array}{c}.820 * * \\
.004 \\
10\end{array}$ & $\begin{array}{c}.875 * * \\
.001 \\
10\end{array}$ & 10 & $\begin{array}{c}.875 * * \\
.001 \\
10\end{array}$ & $\begin{array}{c}.894 * * \\
.000 \\
10\end{array}$ \\
\hline $\begin{array}{c}\text { question } \\
10\end{array}$ & $\begin{array}{l}\text { Pearson Correlation } \\
\text { Sig. (2-tailed) } \\
\text { N }\end{array}$ & $\begin{array}{c}.764 * \\
.010 \\
10\end{array}$ & $\begin{array}{c}.937 * * \\
.000 \\
10\end{array}$ & $\begin{array}{c}1,000 * * \\
.000 \\
10\end{array}$ & $\begin{array}{c}.875 * * \\
.001 \\
10\end{array}$ & 10 & $\begin{array}{c}.972 * * \\
.000 \\
10\end{array}$ \\
\hline Total & $\begin{array}{l}\text { Pearson Correlation } \\
\text { Sig. (2-tailed) } \\
\text { N }\end{array}$ & $\begin{array}{c}.856^{* *} \\
.002 \\
10\end{array}$ & $\begin{array}{c}.938 * * \\
.000 \\
10\end{array}$ & $\begin{array}{l}.972 * * \\
.000 \\
10\end{array}$ & $\begin{array}{c}.894 * * \\
.000 \\
10\end{array}$ & $\begin{array}{l}.972 * * \\
.000 \\
10\end{array}$ & 10 \\
\hline
\end{tabular}

Based on the results of the table above, it can be concluded that from 10 respondents with an rtable value of 0.632 questions numbers 6 to 10 have values, namely (0.856 0.632), (0.938 0.632), (0.972 0.632), (0.894 0.632), (0.972 0.632) are declared valid. 
Table 4. Reality Test Results of Multiple Choice Questions Using SPSS 16.0

Reliability Statistics

\begin{tabular}{|c|c|}
\hline Cronbach's Alpha & N of Items \\
\hline 820 & 6 \\
\hline
\end{tabular}

Based on the results of the table above, it can be seen that rcount is 0.827 . The number of respondents is 10 students, so rtable $=0.632$ at a significant level of $5 \%$. From the results of the table, it shows $0.827>0.632$, this indicated that the multiplechoice test questions are stated to be reliable, so they can be used in research.

Table 5. Reliability Test Results of Stuffed Questions Using SPSS 16.0

Reliability Statistics

\begin{tabular}{|c|c|}
\hline Cronbach's Alpha & N of Items \\
\hline .827 & 6 \\
\hline
\end{tabular}

Based on the results of the table above, it can be concluded that rcount is 0.820 . The number of respondents is 10 students, then $r$ table $=0.632$ at a significant level of $5 \%$. From the results of the table, it shows $0.820>0.632$, this indicated that the test items are stated as reliable, so they can be used in research.

Table 6. Normality Test Results

One-Sample Kolmogorov-Smirnov Test

\begin{tabular}{|c|c|c|c|}
\hline & & experiment & control \\
\hline \multicolumn{2}{|l|}{$\mathrm{N}$} & 28 & 28 \\
\hline \multirow{5}{*}{ Most Extreme Differences } & mean & 80.3571 & 72.8571 \\
\hline & Std. Deviation & 11.62123 & $1.50572 \mathrm{E} 1$ \\
\hline & Absolute & .144 & .164 \\
\hline & Positive & .084 & .096 \\
\hline & negative & -.144 & -.164 \\
\hline \multicolumn{2}{|c|}{ Kolmogorov-Smirnov Z } & .761 & .866 \\
\hline \multicolumn{2}{|c|}{ asymp. Sig. (2-tailed) } & .609 & .441 \\
\hline
\end{tabular}


Based on the results of the table above, it can be seen from Asymp. Sig. (2tailed) the experimental class was 0.609 and the control class was 0.441 . The table shows that the value of Asymp. Sig. (2-tailed) experimental class 0.6090 .05 then the experimental class data is normally distributed and for the control class the Asymp value. Sig. (2-tailed) 0.4410 .05 then the control class data is normally distributed.

\section{Table 7. Homogeneity Test Results}

Test of Homogeneity of Variances

Mark

\begin{tabular}{|c|c|c|c|}
\hline Levene Statistics & df1 & df2 & Sig. \\
\hline 2.161 & 1 & 54 & .147 \\
\hline
\end{tabular}

Based on the results of the table above, it can be seen that the value of Levene Statistic is 2,161 with sig. 0.147 , this means that sig. 0.1470 .05 . It can be concluded that the homogeneity test of the data is homogeneous.

\section{Table 8. Results of t-test}

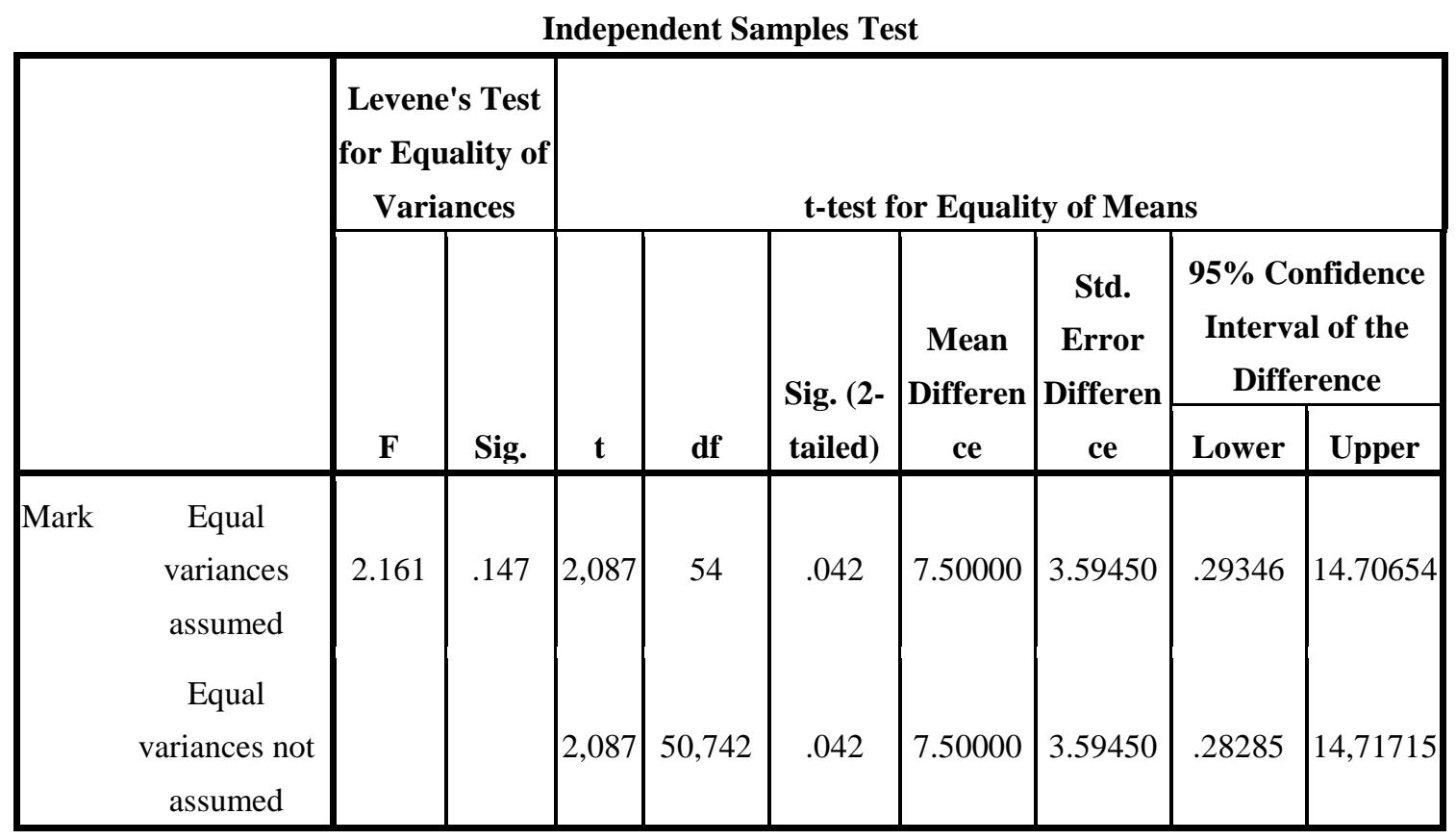

Based on the results of the table above, it can be concluded that there is an effect of multiplication board media video-based in improving mathematics learning outcomes for class II MI Plus Al - Istighotsah Tulungagung students. This can be seen from the results of the analysis on the t-test that the t-count value is 2.087 , while the $\mathrm{t}$ table value is 1.697 at the $5 \%$ significance level with $\mathrm{db}=\mathrm{N}-2=56-2=54$. Based on 
the results of tcount with ttable it can be concluded that tcount $>t$ table is $2.087>1.697$ with sig. (2-tiled) that is $0.042<0.05$

\section{DISCUSSION}

Researchers conducted this research intending to explain the influence of the Multiplication Board media video-based in improving mathematics learning outcomes for class II students MI Plus Al-IstighotsahTulungagung. The researcher before determining the research sample carried out a homogeneity test of the three classes using the daily math test scores. Obtained significance is 0.820 which is greater than the level of 0.05 or $0.820>0.05$, then the three classes are declared homogeneous.

Next, the researcher conducted a validation and reliability test on the post-test questions before the questions were given to the research sample. From the results of the validation test on multiple-choice questions, it shows that of 10 respondents with an rtable value of 0.632 from question number 1 to question number 5 has a value that is (0.902 0.632), (0.902 0.632), (0.923 0.632), (0.923 0.632), (0.902 0.632) are declared valid. And the questions filled in from 10 respondents with an rtable value of 0.632 , questions numbered 6 to 10 have values, namely (0.856 0.632), (0.938 0.632), (0.972 0.632), (0.894 0.632), (0.972 0.632) are declared valid. While the results of the reliability test on multiple-choice questions it is known that rcount is 0.827 . The number of respondents is 10 students, then $r$ table $=0.632$ at a significant level of $5 \%$. From the results of the table, it shows $0.827>0.632$, this indicates that the multiple-choice test questions are stated to be reliable.

Researchers conducted a t-test to determine the effect of multiplication board media video-based in improving the mathematics learning outcomes of class students MI Plus Al-Istighotsah Tulungagung during the covid-19 pandemic. Before conducting the t-test, first, the researcher conducted a homogeneous test and a normal distribution.

Based on the results of the research data shows that there is a significant difference that can be seen from the results of the t-test, the t-count value obtained is 2.087 and the value in ttable is at a significance level of $5 \%$ with $\mathrm{db}=\mathrm{N}-2=56-2=54$ at ttable is 1.697 , so we get $2.087>1.697$ with sig. (2-tiled) $0.042<0.05$.

The results of this study are strengthened by previous research from Rismayani Armin and Waode Hensi Purwati in their journal entitled the effect of using the 
multiplication smart board media on the mathematics learning outcomes of the second grade of multiplication material at SDN 75 Buton in their journal concluded that the experimental group student learning outcomes were higher, that is 77.5 , while the learning outcomes of control students were 73.5. From the results of hypothesis testing using the t-test, it can be obtained the value of tcount $=0.187$ with $\mathrm{df}=14$ sig. (2-tiled)at $0.001<(0.05)$.

Reinforced by Lalita Nurfi Kurniawati who stated that the multiplication board media used in the learning process was more fun, students were more active and directly involved in the use of the multiplication board media. Students are easier to learn multiplication and easy to remember.

Reinforced by Arif Yudianto who stated that Video is one of the learning media that can be seen and heard very effectively to support the learning process. Both face-toface learning and online learning (distance learning). The selection of video media as a tool to convey material to students in addition to innovation can also combine audio and visual which can make it easier for students to receive messages and understand the content of the material. Video becomes effective to use because it can be viewed repeatedly, can be reproduced.

Based on the explanation above, it is concluded that the use of multiplication board media video-based can improve the Mathematic learning outcomes of class II students MI Plus Al-Istighotsah Tulungagung.

\section{CONCLUSION}

Based on the results of the study, there is a significant effect Multiplication Board media video-based in improving grade II mathematics learning outcomes MI Plus Al-Istighotsah Tulungagung. This is based on the results of the t-test analysis can be $2,087>1,697$ with sig. (2-tiled) $0.042<0.05$. Based on the explanation above, it is concluded that the use of multiplication board media video-based can improve mathematics learning outcomes for class II students of MI Plus Al-Istighotsah Tulungagung.

\section{REFERENCES}


Abdul Latip. 2020. Peran literasi Teknologi informasi Dan Komunikasi Pada Pembelajaran Jarak jauh di Masa Pandemi Covid-19. Jurnal Edukasi Dan Pendidikan Teknologi, No. 2, Vol. 1.

Ahmar, Ansari Saleh. 2019. Berhitung Cepat Matematika Perkalian. Sulawesi: Yayasan Ahmar Cendekia Indonesia.

Arif Yudianto. 2017. Penerapan Video Sebagai Media Pembelajaran, seminar pendidikan nasional.

Danoebroto, Sri Wulandari. 2012. Model Pembelajaran Matematika Berbasis Pendidikan Multikultural. Jurnal Pembangun Pendidikan: Fondasi dan Aplikasi. Vo. 1 No. 1

Erman Suherman, dkk. 1992. Strategi Belajar Mengajar Matematika. Jakarta: Universitas Terbuka.

Falahudin, Iwan. 2014. Pemanfaatan Media Dalam Pembelajaran. Jurnal Lingkar Widyaiswara. Vol. 1 No. 4

Inarotul Humaero dkk, Upaya peningkatan Hasil Belajar Matematika Materi Perkalian melalui Media Papan Napier Kelas III Di SD Negeri Kalisabuk 03 Tahun 2019, Jurnal Pancar, Vol 3 No. 2, November 2019

Istiqlal, Abdul. 2018. Manfaat Media Pembelajaran Dalam Proses Belajar Dan Mengajar Mahasiswa di Perguruan Tinggi, Jurnal Kepemimpinan dan Pengurusan Sekolah. Vol. 3. No. 2.

Keke T. Aritonang. 2008. Minat dan Motivasi Dalam Meningkatkan Hasil Belajar Siswa. Jurnal Pendidikan Penabur. No. 10

Kerlinger. 2006. Asas-asas Penelitian Behavioral Ediisi Ketiga. Yogjakarta: Gajah Mada University Press.

Kustiawan, Usep. 2016. Pengembangan Media Pembelajaran Anak Usia Dini. Malang: Gunung Samudera. 
Kusuma, Jaka Wijaya, Hamidah. 2020. Perbandingan Hasil Belajar Matematika Dengan Penggunaan Platform wahtsapp Group Dan Webinar Zoom Dalam Pembelajaran Jarak Jauh Pada Masa Pandemi Covid-19. Jurnal Pendidikan Matematika. Vol. 5. No. 1

Lailita Nurfi Kurniawati. 2021. Meningkatkan Hasil Belajar Siswa Pada Materi Perkalian Menggunakan Papan Perkalian. Jurnal Tindakan Kelas. Vol.2. No. 1

Luh Devi Herlindry. 2020. Pembelajaran Pada Masa Pandemi Covid-19. Jurnal Teknologi Pendididkan, Vol.22, No. 1.

Mahnun, Nunu. 2012. Media Pembelajaran. Jurnal Pemikiran Islam. Vol. 37. No. 1

Nurrita, Teni. 2018. Pengembangan Media Pembelajaran Untuk meningkatkan Hasil Belajar Siswa. Jurnal Musykat. Vol. 03. No. 01.

Prayitno. 2013. Dasar Teori dan Praktisis Pendidikan. Yogyakarta: Grasindo.

Rike Andriani, Rasto. 2019. Motivasi Belajar Sebagai Determinan Hasil Belajar Siswa. Jurnal Pendidikan Manajemen Perkantoran. Vo. 4. No. 1

Rismayani Armin dan Waode Hensi Purwati. 2021. Pengaruh Penggunaan Media Papan Cerdas Perkalian Terhadap Hasil Belajar Matematika Materi Perkalian Siswa Kelas II Di SD Negeri 75 Buton. Jurnal Akademik Pendidikan Matematika.

Rusyan, Tabrani. 2006. Kunci Sukses belaja. Bandung: Sinergi Pustaka Indonesia.

Sulihin B. Sjukur. 2012. Pengaruh Blended Learning Terhadap Motivasi Belajar Dan Hasil Belajar Siswa Tingkat SMK. Jurnal Pendidikan Vokasi. Vol. 2 No. 3.

Sumiharsono, Rudy. 2018. Media Pembelajaran. Jember: CV Pustaka Abadi.

Vivi Fitria Dewi, dkk. 2020. Pengaruh Penggunaan Jarimatika Terhadap Kemampuan Berhitung Perkalian Peserta didik Kelas IV Sekolah Dasar. Jurnal Pendidikan Dasar. Vol. 2. No. 2 
Widayanti, L. 2014. Peningkatan Aktivitas Belajar Dan Hasil Belajar Siswa Dengan Metode Problem Based Learning Pada Siswa Kelas VII A MTs Negeri Donomulyo Kulon Progo Tahun Pelajaran 2012/2013. Jurnal Fisika Indonesia. 